\title{
An (U-Th)/He age for the shallow-marine Wetumpka impact structure, Alabama, USA
}

\author{
Jo-Anne WARTHO ${ }^{1 *}$, Matthijs C. van SOEST ${ }^{1}$, David T. KING, JR. $^{2}$, and Lucille W. PETRUNY ${ }^{2}$ \\ ${ }^{1}$ School of Earth and Space Exploration, Arizona State University, PO Box 876004, Tempe, Arizona 85287, USA \\ ${ }^{2}$ Geology Office, Auburn University, Auburn, Alabama 36849, USA \\ *Corresponding author. E-mail: jo-anne.wartho@asu.edu
}

(Received 12 January 2012; revision accepted 27 May 2012)

\begin{abstract}
Single crystal (U-Th)/He dating was applied to 24 apatite and 23 zircon grains from the Wetumpka impact structure, Alabama, USA. This small approximately 5-7.6 km impact crater was formed in a shallow marine environment, with no known preserved impact melt, thus offering a challenge to common geochronological techniques. A mean (U-Th)/He apatite and zircon age of $84.4 \pm 1.4 \mathrm{Ma}(2 \sigma)$ was obtained, which is within error of the previously estimated Late Cretaceous impact age of approximately $83.5 \mathrm{Ma}$. In addition, helium diffusion modeling of apatite and zircon grains during fireball/contact, shock metamorphism, and hydrothermal events was undertaken, to show the influence of these individual thermal processes on resetting (U-Th)/He ages in the Wetumpka samples. This study has shown that the (U-Th)/He geochronological technique has real potential for dating impact structures, especially smaller and eroded impact structures that lack impact melt lithologies.
\end{abstract}

\section{INTRODUCTION}

A major development in Earth sciences over the past decade has been the widespread appreciation of the importance of bolide impact events on the geological and biological history of Earth. Obtaining more accurate and precise ages for the Earth's impact events will help identify any local- or global-influencing impact-related biotic effects and will help us understand possible clustering of impacts in the stratigraphic record.

The main challenge in dating impact structures is that isotope systematics of the traditionally applied geochronometers (e.g., K-Ar, Sm-Nd, Rb-Sr, and U-Pb) in $90 \%$ of the target rocks and minerals are not completely reset during these short but very intense hypervelocity impact events, thus making geochronological dating very difficult (Schärer and Deutsch 1990; Deutsch and Schärer 1994). Approximately $75 \%$ of known terrestrial impact structures have either never been dated or have poorly constrained geochronological ages (i.e., $>10 \%$ errors; Earth Impact Database 2012). Many of these ages were obtained by traditional stratigraphic dating; however, there are many problems and pitfalls associated with these techniques (e.g., Schmieder and
Buchner 2008). An ideal chronometer for dating impact structures would require a low closure temperature and a fast diffusion rate for the radiogenic daughter product. The $(\mathrm{U}-\mathrm{Th}) / \mathrm{He}$ dating technique meets these two criteria, and offers a new geochronological method for providing accurate ages for impact structures (van Soest et al. 2011). Previous studies using the low-temperature apatite fission-track chronometer have yielded mixed results (e.g., Wagner and Storzer 1975; Miller and Wagner 1979; Weber et al. 2005), and the best fission track results often come from dating tektite glasses or apatites from suevites. However, these rocks units are often absent from small, marine, or deeply eroded impact structures.

Wetumpka is an approximately $5-7.6 \mathrm{~km}$ diameter, marine-target impact structure located in the inner Gulf coastal plain of Alabama (Fig. 1a; Neathery et al. 1976; King et al. 2002, 2006a; King and Ormö 2011). Based on new a LIDAR study of the crater (King, personal communication), a diameter of $6.25 \mathrm{~km}$ has been calculated. Paleogeographical studies show that the Wetumpka impact occurred in shallow marine water approximately $30-100 \mathrm{~m}$ in estimated depth (King et al. 2007), and within approximately $25 \mathrm{~km}$ of the local 
(a)

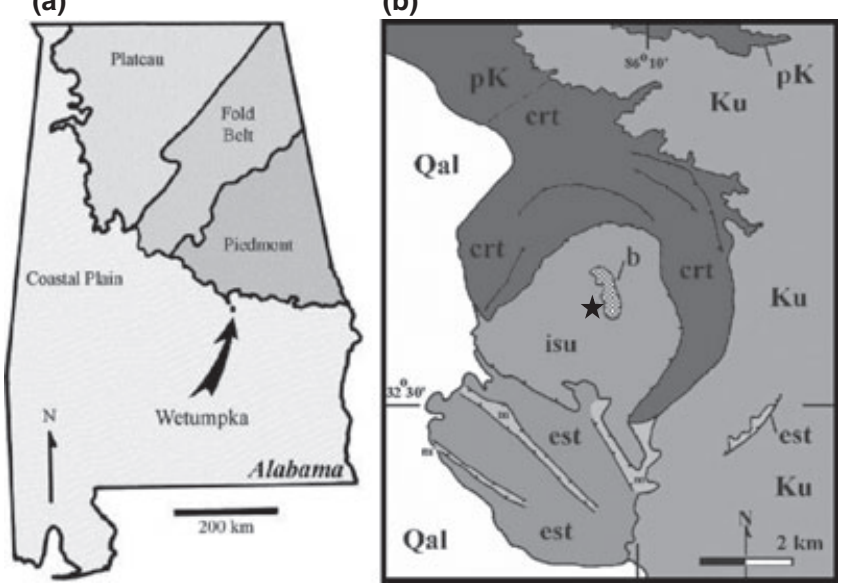

Fig. 1. (a) Location map of the Wetumpka impact structure in Alabama, showing the major geological provinces. (b) Geological map of the Wetumpka structure. Labels: crt = crystalline-rim terrain, isu $=$ intra-structure terrain, est $=$ extra-structure terrain, $\mathrm{Ku}=$ Upper Cretaceous undeformed units, $\mathrm{pK}=$ pre-Cretaceous crystalline units unaffected by the impact structure, Qal = Quaternary alluvium, $\mathrm{m}=$ Mooreville Chalk, $\mathrm{b}=$ impact breccias, and black star $=$ drilling locations of Schroeder and Reeves wells (from King et al. 2002).

barrier-island shoreline (King 1997; King et al. 2002, 2003, 2006a). Similar to the $5.1 \mathrm{~km}$ diameter Goat Paddock impact structure (Milton and Macdougall 2006), Wetumpka is transitional between a simple, bowlshaped crater and a complex impact structure, and possesses only a muted central peak (King et al. 2006a; King and Ormö 2011). The Wetumpka target materials consisted of approximately $30-100 \mathrm{~m}$ of water, poorly consolidated sediment, comprising three Upper Cretaceous stratigraphic units: approximately $30 \mathrm{~m}$ of chalky ooze (Mooreville Chalk), approximately $30 \mathrm{~m}$ of paralic marine sand (Eutaw Formation), and approximately $60 \mathrm{~m}$ of terrestrial clayey sand and gravels (Tuscaloosa Group), and at the base a pre-Cretaceous crystalline complex of gneisses and schists (Emuckfaw Group schists and Kowaliga gneisses; Fig. 1b; King et al. 2002, 2006a).

Neathery et al. (1976) first mapped and described the geology of this structure, and suggested that the physiography and geology of the area were consistent with a cosmic impact, which they estimated occurred between the Late Cretaceous and Pleistocene. Later, an early Campanian stratigraphic age was proposed for the Wetumpka impact structure based on biostratigraphic ages of the youngest layers involved in the impact deformation (i.e., the lower beds of the Mooreville Chalk [King 1997]). King et al. (2007) again reviewed the biostratigraphic evidence and estimated that the impact may have been near the local boundary between two planktonic foraminiferal biozones: Dicarinella asymetrica range zone and Globotruncanita elevata interval zone (regional biozones of Mancini et al. 1988). The age of this biozone boundary was estimated at approximately $83.5 \mathrm{Ma}$ (King et al. 2006b) using the 1988 global synthesis of sequence stratigraphy and biostratigraphy (Haq et al. 1988). This approximately $83.5 \mathrm{Ma}$ age coincides with the Upper Cretaceous Santonian/ Campanian boundary (Gradstein et al. 2004; Ogg et al. 2008).

In this study, we present the results of a singlecrystal apatite and zircon (U-Th)/He dating project on five impact breccia samples from drill cores obtained from the central uplift region. Our results represent the first radiometric age for the Wetumpka impact structure. In addition, $\mathrm{He}$ diffusion modeling was undertaken to explain how the Wetumpka (U-Th)/He apatite and zircon ages may have been partially/completely reset during this impact event.

\section{METHODS AND RESULTS}

Five samples were obtained from drill cores taken from two wells (the Schroeder well [98-01] and the Reeves well [98-02]) at depths ranging from 107.70 to $135.88 \mathrm{~m}$ and 112.47 to $136.86 \mathrm{~m}$, respectively (Table 1; King et al. 2002; Johnson 2007). The samples consisted of friable, polymict impact breccias, which contained numerous altered clasts of varying size from the crystalline Emuckfaw Group schists and Kowaliga gneisses (King et al. 2002). The friable samples were pestle and mortar crushed, wet sieved, magnetically and heavy liquid-separated to yield heavy mineral fractions of apatite and zircon. Between 2 and 9 individual zircon and apatite crystals were (U-Th)/He dated from all five samples (Fig. 2).

Euhedral and inclusion-free (in the case of apatite) apatite and zircon crystals were selected from the heavy mineral separates using a Leica MZ16 zoom binocular microscope with up to $\times 184$ magnification, equipped with a camera and capable of dark-field illumination (Fig. 2). Digital images were taken from at least two different faces of the crystals, and the dimensions of each crystal were made to allow $\alpha$-ejection corrections to be made (Farley et al. 1996). To ensure that the measurements were correct, each microscope magnification setting and the camera were calibrated using a traceable NIST ruler. Each measured crystal was inserted into a small $0.027^{\prime \prime} \mathrm{OD} \times 0.04^{\prime \prime}$ long $\mathrm{Nb}$ tube, which was placed in a 25 hole stainless steel sample holder, along with 2 blank $\mathrm{Ni}$ tubes, and 3 tubes containing age standards, using either a shard of Durango apatite (for apatite unknowns) or a Fish Canyon zircon crystal (for zircon unknowns) as age standards. The holder was 


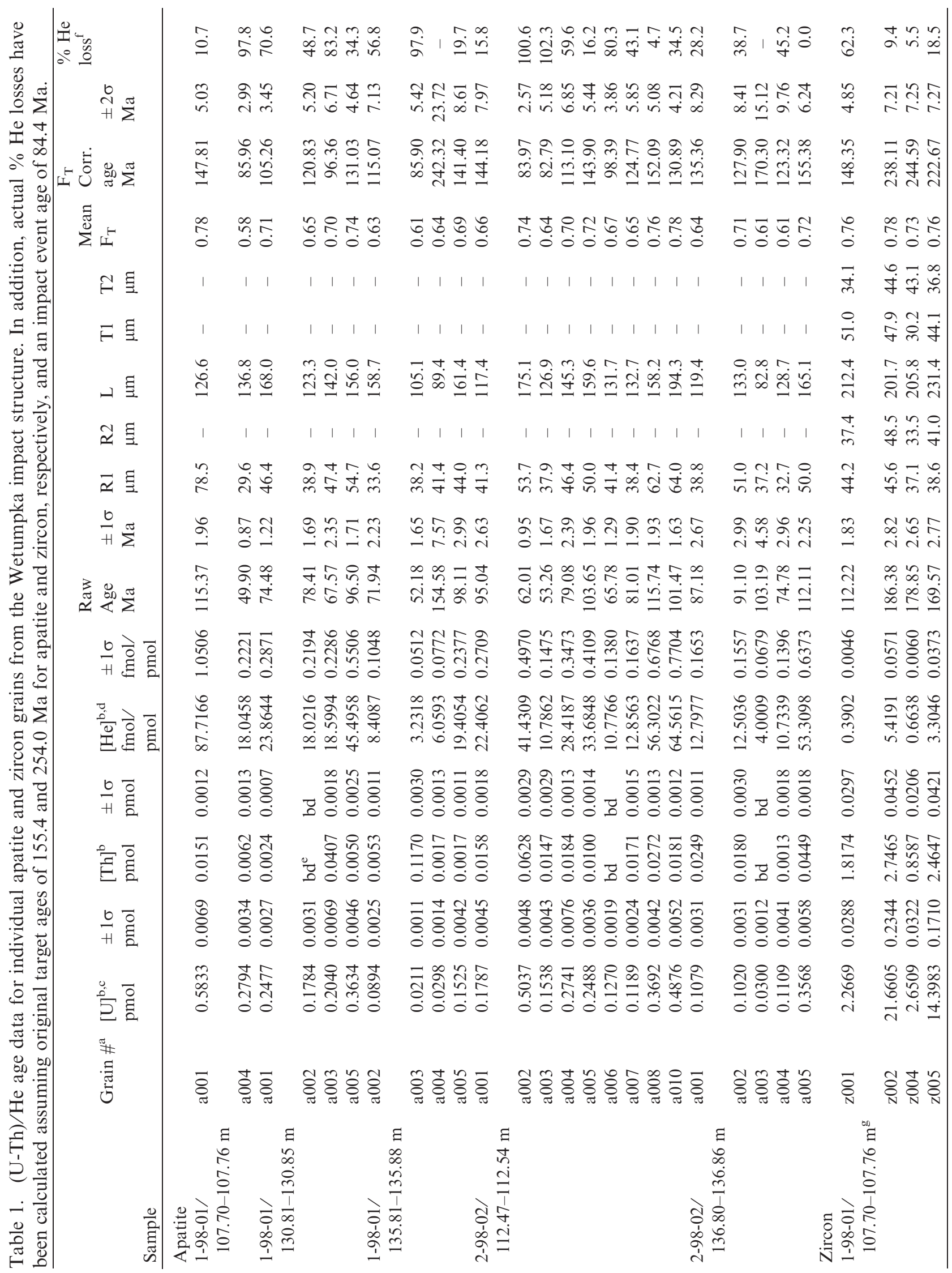




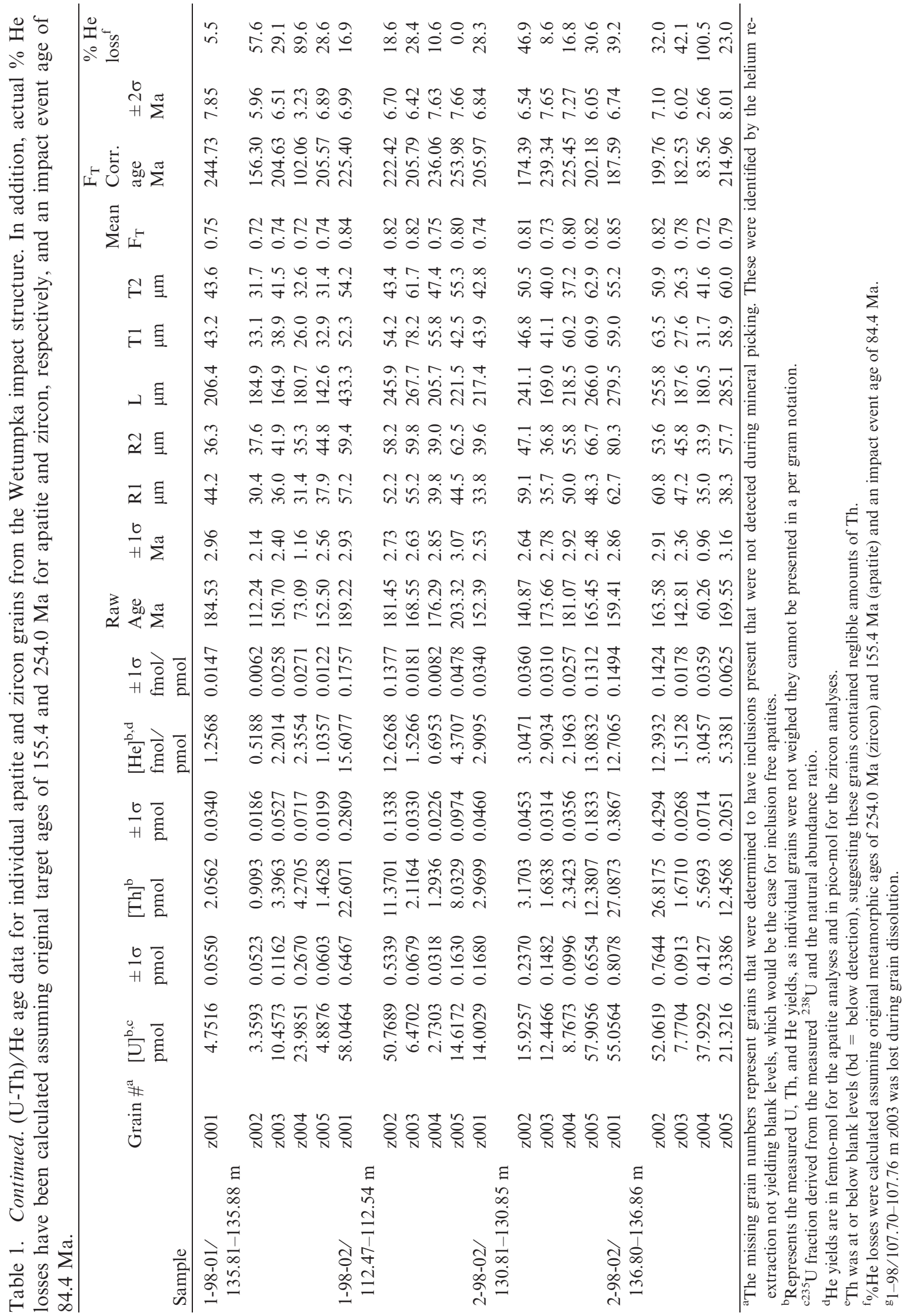




\section{Apatites}

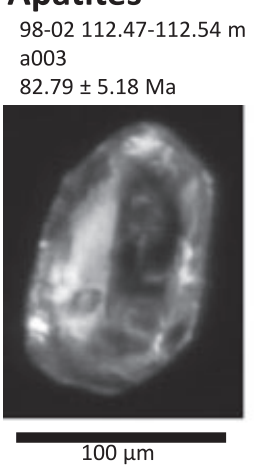

\section{Zircons}

98-02 136.80-136.86 m z004

$83.56 \pm 2.66 \mathrm{Ma}$

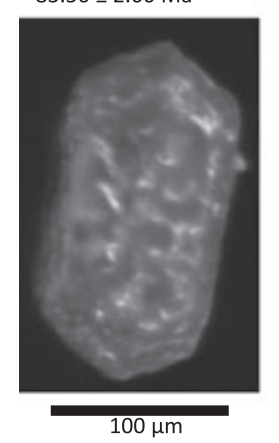

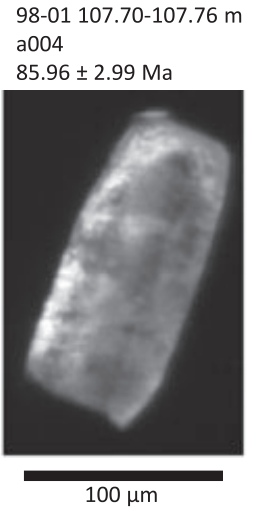

98-01 135.81-135.88 m z004

$102.06 \pm 3.23 \mathrm{Ma}$

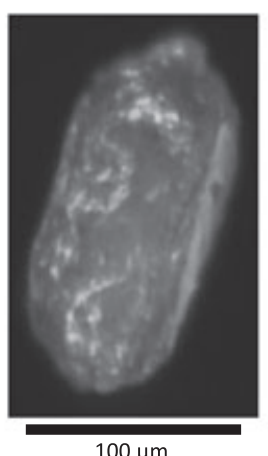

98-01 130.81-130.85 m $\mathrm{a} 003$

$96.36 \pm 6.71 \mathrm{Ma}$

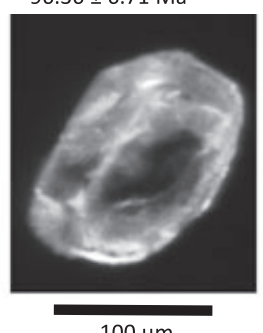

$100 \mu \mathrm{m}$

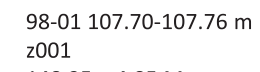

$148.35 \pm 4.85 \mathrm{Ma}$

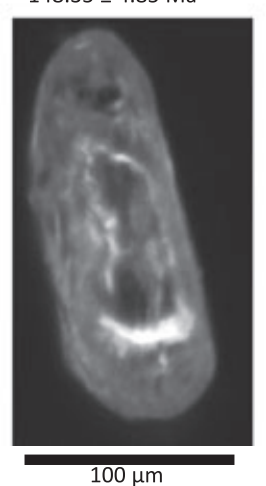

98-02 136.80-136.86 m a002

$127.90 \pm 8.41 \mathrm{Ma}$

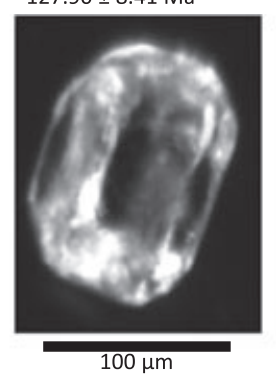

98-01 135.81-135.88 m z002

$156.30 \pm 5.96 \mathrm{Ma}$

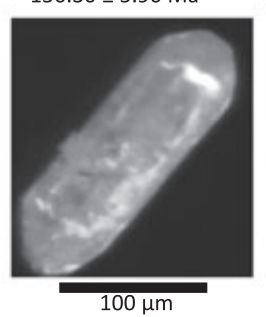

98-02 136.80-136.86 m a005

$155.38 \pm 6.24 \mathrm{Ma}$

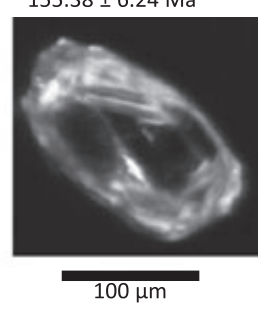

98-02 112.47-112.54 m z005

$253.98 \pm 7.66 \mathrm{Ma}$

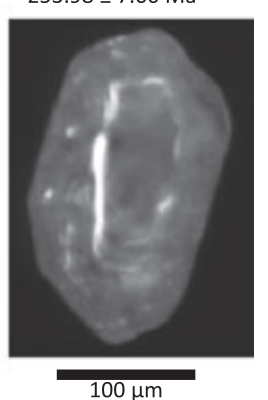

Fig. 2. Black and white optical microscope photomicrographs of apatite and zircon grains.

loaded into a sapphire-viewport laser chamber and extraction line of the Australian Scientific Instruments Alphachron in the Noble Gas Geochemistry and Geochronology Laboratories $\left(\mathrm{NG}^{3} \mathrm{~L}\right)$ at ASU and pumped down overnight. ${ }^{4} \mathrm{He}$ was extracted from the samples by laser heating using a $980 \mathrm{~nm}$ infra-red diode laser (11 A [approximately $4 \mathrm{~W}$ ] for $5 \mathrm{~min}$ for apatite, and $15 \mathrm{~A}$ [approximately $8 \mathrm{~W}$ ] for $10 \mathrm{~min}$ for zircon). This extracted gas was spiked with ${ }^{3} \mathrm{He}$ and exposed to a hot SAES NP-10 getter for $2 \mathrm{~min}$. The gas was expanded into a Pfeiffer-Balzers Prisma quadrupole mass spectrometer with a 0-100 amu range, a Channeltron electron multiplier and a Faraday detector, which also contains a room temperature SAES NP-10 getter in the vacuum chamber.

Helium blanks were determined by laser heating the $\mathrm{Nb}$ blank tubes following the apatite and zircon procedures. The long-term average for the ${ }^{4} \mathrm{He}$ blanks was $0.036 \pm 0.010$ femtomole for all procedures, and the blanks for the system during the analytical runs all fell within that range. ${ }^{4} \mathrm{He}$ abundances for the unknowns were between 90-2437 times the blank for apatite, and 10,840-433,537 times the blank for zircon analyses. To analyze the ${ }^{4} \mathrm{He} /{ }^{3} \mathrm{He}$ composition of the gas, 4 masses were monitored during analyses: mass 1 as a proxy for HD contributions to the mass 3 peak, mass 3 for ${ }^{3} \mathrm{He}$, mass 4 for ${ }^{4} \mathrm{He}$, and mass 5 for background. The hydrogen deuteride (HD) contribution to the ${ }^{3} \mathrm{He}$ peak ranged from 0.035 to $0.040 \%$ for apatite, and from 0.045 to $0.055 \%$ for zircon analyses. ${ }^{4} \mathrm{He}$ concentrations were calculated by comparing the sample ${ }^{4} \mathrm{He} /{ }^{3} \mathrm{He}$ ratios to a set of standard analyses run prior to and after the unknown analyses. Short-term (5-10 standard analyses) reproducibility was on the order of $0.03-0.05 \%$, while the long-term complete (sample holder run) reproducibility was $0.05-0.08 \%$. The composition of the ${ }^{4} \mathrm{He}$ standard gas tank is known to be $1.2 \%$, which represents that largest contribution to the error in this part of the analytical analysis. After initial $\mathrm{He}$ laser extraction, all the samples were re-extracted with the same laser heating analytical procedure. In all cases, the apatites re-extracted perfectly to blank levels, while the zircons were re-extracted until He yields were $<0.5 \%$ of the originally extracted gas. On occasion, this required multiple laser heating re-extractions. The reasons for incomplete $\mathrm{He}$ degassing are poorly understood, but it 
does not appear to negatively affect the final ages calculated (e.g., Reiners 2005).

Following $\mathrm{He}$ measurement, the $\mathrm{Nb}$ tubes containing the grains were unloaded and acid digested for $\mathrm{U}$ and $\mathrm{Th}$ analysis on an inductively coupled plasma mass spectrometer (ICP-MS). The acid digestion procedures for apatite and zircon are different, and are outlined below. Apatite crystals and $\mathrm{Nb}$ tubes were dissolved in concentrated $\mathrm{HNO}_{3}$ (Evans et al. 2005), while zircon crystals and $\mathrm{Nb}$ tubes required the use of concentrated $\mathrm{HF}, \mathrm{HNO}_{3}$, and $\mathrm{HCl}$ combined with higher temperatures and pressures (Reiners et al. 2002; Reiners 2005). As the tubes were dissolved during the acid digestion process, this precluded the use of $\mathrm{Pt}$ tubes as large amounts of $\mathrm{Pt}$ in solution cause severe PtAr interferences on the U peak in the ICP-MS, hence $\mathrm{Nb}$ tubes were used. $\mathrm{Nb}$ has a high melting point, so it does not melt during laser heating and it has a low atomic mass, which means that $\mathrm{NbAr}$ complexes do not cause interferences on the $\mathrm{U}$ peak.

$\mathrm{Nb}$ tubes containing apatite crystals were transferred into $1.5 \mathrm{~mL}$ polypropylene microvials and a $25 \mu \mathrm{L}{ }^{235} \mathrm{U}$ and ${ }^{230} \mathrm{Th}$ spike solution aliquot (made up in $50 \%$ distilled ultra-pure $\mathrm{HNO}_{3}$ ) was added. The ${ }^{235} \mathrm{U}$ and ${ }^{230} \mathrm{Th}$ spike solution had a concentration of 15 and $5 \mathrm{ng} \mathrm{mL}^{-1}$, respectively. Samples were then placed in an ultrasonic bath for $15 \mathrm{~min}$ and rested for $4 \mathrm{~h}$ to allow the apatites to dissolve. After this, the samples were diluted with $375 \mu \mathrm{L}$ of MilliQ 18.2 M $\Omega$ polished water to make up the final solution for ICP-MS analysis.

Zircon crystals were dissolved following general procedures described by Reiners (2005). The Nb tubes containing the crystals were transferred into Teflon microvials $(0.50 \mathrm{~mL})$ and $50 \mu \mathrm{L}$ of the same ${ }^{235} \mathrm{U}$ and ${ }^{230} \mathrm{Th}$ spike solution used for the apatite analyses was added, together with $300 \mu \mathrm{L}$ of distilled ultra-pure concentrated HF. The vials were then put in the Teflon liners of large $125 \mathrm{~mL}$ Parr digestion vessels that each held 10 vials. To balance the pressure in the Parr vessels, $10 \mathrm{~mL}$ of trace metal grade concentrated $\mathrm{HF}$ and $0.45 \mathrm{~mL}$ of trace metal grade concentrated $\mathrm{HNO}_{3}$ were added to the Teflon liner. The digestion vessels were heated at $225^{\circ} \mathrm{C}$ for $72 \mathrm{~h}$, after which the samples were dried at a low heat $\left(60-75^{\circ} \mathrm{C}\right)$. When the samples in the vials were dry, they were put back into the Parr digestion vessels, and $300 \mu \mathrm{L}$ of distilled ultrapure concentrated $\mathrm{HCl}$ was added to each vial, and $9 \mathrm{~mL}$ of trace metal grade concentrated $\mathrm{HCl}$ was added to the liner. The Parr vessels were heated at $200^{\circ} \mathrm{C}$ for $24 \mathrm{~h}$. Following this, the samples in the vials were again heated to dryness at $60-70{ }^{\circ} \mathrm{C}$ for $30 \mathrm{~min}$, and $12.5 \mu \mathrm{L}$ of distilled ultrapure concentrated $\mathrm{HF}$ and $100 \mu \mathrm{L}$ of distilled ultrapure concentrated $\mathrm{HNO}_{3}$ were then added to each vial. The sample vials were closed and gently heated on a hot plate at $60-70{ }^{\circ} \mathrm{C}$ for $30 \mathrm{~min}$, before the contents were transferred to larger $15 \mathrm{~mL}$ polypropylene vials containing $1.5 \mathrm{~mL}$ of MilliQ 18.2 $\mathrm{M} \Omega$ polished water to make up the final solution of $0.8 \% \mathrm{HF}$ and $6 \%$ of $\mathrm{HNO}_{3}$ for ICP-MS analysis.

The solutions were analyzed on a Thermo X Series quadrupole ICP-MS in the W. M. Keck Foundation Laboratory for Environmental Geochemistry at ASU, using a micro-nebulizer with an uptake rate of $100 \mu \mathrm{L} \mathrm{min}{ }^{-1}$. The analytical procedure consisted of 7 and 10 cycles for apatite and zircon solutions, respectively. For each cycle, 150 scans of the following isotopes were conducted: ${ }^{230} \mathrm{Th},{ }^{232} \mathrm{Th},{ }^{235} \mathrm{U},{ }^{238} \mathrm{U}$, and ${ }^{234} \mathrm{U}$, with ${ }^{234} \mathrm{U}$ being used as a proxy for detection of isobaric interferences on the $U$ mass spectrum due to PtAr. During the apatite analyses ${ }^{147} \mathrm{Sm},{ }^{152} \mathrm{Sm}$, and ${ }^{154} \mathrm{Sm}$ were also analyzed to determine if any of the apatites have high enough $\mathrm{Sm}$ contents to have a significant effect on the calculated (U-Th)/He age. As there was no $\mathrm{Sm}$ isotope in the spike solution, actual $\mathrm{Sm}$ abundances in the solution could not be calculated. However, none of the apatites analyzed in this study had high enough $\mathrm{Sm}$ concentrations to affect the (U-Th)/He ages.

Analyses were standardized by analyzing a spiked standard (SPST) solution, which was a mixture of the same spike solution used for the apatite and zircon solutions, plus a $U$ and $T h$ standard of known concentration. For SPST solutions run with the apatite samples, $25 \mu \mathrm{L}$ of spike was added to $25 \mu \mathrm{L}$ of the standard solution, which had a concentration of $25 \mathrm{ng} \mathrm{mL}^{-1}$ of $\mathrm{U}$ and $\mathrm{Th}$ in $4 \% \mathrm{HNO}_{3}$, that was then diluted with $350 \mu \mathrm{L}$ MilliQ $18.2 \mathrm{M} \Omega$ polished water to make the final solution. For zircon samples, $50 \mu \mathrm{L}$ of the spike was mixed with $50 \mu \mathrm{L}$ of the standard solution to which $100 \mu \mathrm{L}$ of distilled ultra-pure concentrated $\mathrm{HNO}_{3}$ and $12.5 \mu \mathrm{L}$ of distilled ultra-pure concentrated HF were added. The solution was then diluted with $1.5 \mathrm{~mL}$ of MilliQ 18.2 M $\Omega$ polished water to make up the final solution of $0.8 \% \mathrm{HF}$ and $4-6 \% \mathrm{HNO}_{3}$ for analysis. One SPST solution was also added to each Parr digestion vessel to monitor for any effects of contamination during the Parr digestion process. So far, we have not encountered any major differences between the SPST solutions that have gone through the Parr digestion process and those that were prepared without going through that process. Reproducibility of the spiked standard analysis was on the order of $0.75 \%$ for $U$ and $0.85 \%$ for $\mathrm{Th}$.

The total blank analyses were determined by taking the empty $\mathrm{Nb}$ tubes (used to determine the $\mathrm{He}$ blanks) and processing them with the samples through the acid digestion steps for $\mathrm{U}$ and $\mathrm{Th}$ analysis. Average $\mathrm{Nb}$ tube blanks for the apatite procedure were $0.65 \pm 0.08 \mathrm{pg}(1 \sigma)$ for $U$ and $0.48 \pm 0.02 \mathrm{pg}$ 
$(1 \sigma)$ for $\mathrm{Th}$, while the average $\mathrm{Nb}$ tube blanks for the zircon procedure were higher at $2.73 \pm 0.11 \mathrm{pg}(1 \sigma)$ for $\mathrm{U}$ and $3.31 \pm 0.27 \mathrm{pg}$ for $\mathrm{Th}(1 \sigma)$, reflecting the fact that the tube had totally dissolved during the zircon digestion procedure.

Ages were iteratively calculated using blank corrected $\mathrm{He}, \mathrm{Th}$, and $\mathrm{U}$ values. Raw ages were corrected for $\alpha$-ejection effects following methods described in Farley et al. (1996) and Farley (2002) for apatite and Hourigan et al. (2005) and Reiners (2005) for zircon. The long-term average age determined for Durango apatite in the $\mathrm{NG}^{3} \mathrm{~L}$ was $31.72 \pm 1.30 \mathrm{Ma}(1 \sigma$ standard deviation) with a standard error of $0.06 \mathrm{Ma}$ $(n=408)$. The equivalent weighted average age calculated with ISOPLOT 3.7 (Ludwig 2008-with no rejections allowed) was $31.63 \pm 0.15 \mathrm{Ma} \quad(95 \%$ confidence, Mean Square Weighted Deviation [MSWD] = 5.8) for Durango apatite, and for Fish Canyon zircon it was $27.9 \pm 1.36 \mathrm{Ma}(1 \sigma$ standard deviation $)$ with a standard error of $0.14 \mathrm{Ma}(n=96)$. The equivalent weighted average age calculated with ISOPLOT 3.7 (Ludwig 2008 - with no rejections allowed) was 27.71 $\pm 0.26 \mathrm{Ma}(95 \%$ confidence, MSWD $=35)$. All the age standards analyzed with the samples fell within the age population defined by our long-term running averages. Analytical errors were propagated throughout the process and amount to $1.5-2.5 \%(1 \sigma)$. Errors associated with the $\alpha$-ejection correction were not directly determined, but following discussions in Farley et al. (1996), Spotila et al. (1998), and Hourigan et al. (2005), they are estimated to push the total error for the method to $3-4 \%(1 \sigma)$. The $\alpha$-ejection corrections were made assuming a homogeneous $\mathrm{U}$ and $\mathrm{Th}$ distribution, which, especially for zircon, may often not be fully realistic and can account for significant added scatter in the age data (e.g., Hourigan et al. 2005). A detailed description of the analytical procedures is also provided in van Soest et al.'s (2011) Supplementary Data File S1 and auxiliary table, which is available online.

Twenty-three zircon grains gave (U-Th)/He ages ranging from $83.6 \pm 2.7$ to $254.0 \pm 7.7 \mathrm{Ma}$, and 24 apatite (U-Th)/He analyses yielded ages ranging from $82.8 \pm 5.2$ to $242.3 \pm 23.7 \mathrm{Ma}(2 \sigma$, Table 1$)$. The 83-242 Ma age range is interpreted to reflect a set of partially to completely reset (U-Th)/He ages, with an obvious young cluster of 5 ages at $82.8-86.0 \mathrm{Ma}$ (4 apatite and 1 zircon age; Fig. 3). These five youngest ages yielded a mean age of $84.4 \pm 1.4 \mathrm{Ma}(2 \sigma$ internal errors, $\quad$ MSWD $=0.57 ; \quad$ probability $=0.68)$ using Isoplot 3.7 (Ludwig 2008), and is therefore estimated to be the date of the Wetumpka impact event. This radiometric age agrees very well with the previous biostratigraphic age of approximately $83.5 \mathrm{Ma}$ for the Wetumpka impact structure (King et al. 2006b).

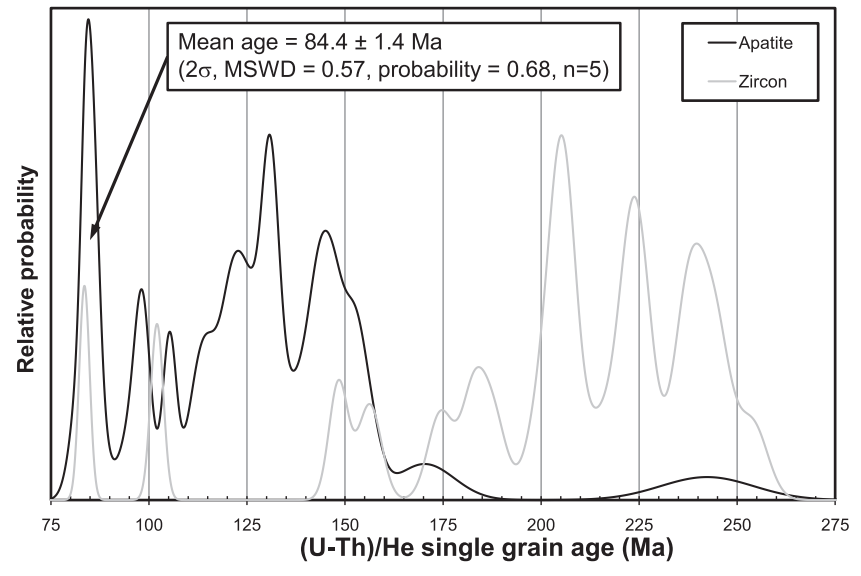

Fig. 3. Probability density plots of $(\mathrm{U}-\mathrm{Th}) / \mathrm{He}$ apatite $(n=23)$ and zircon $(n=24)$ ages from five Wetumpka drill core samples.

\section{HE DIFFUSION MODELING OF IMPACT EVENTS AT WETUMPKA}

During initial impact, i.e., the fireball event, temperatures of $>10,000 \mathrm{~K}$ can occur near the impact point (French 1998; Collins et al. 2005) and much of the surrounding rocks typically reach $500-3000{ }^{\circ} \mathrm{C}$ during these very short-lived events (French 1998). Shock metamorphism can also result in significant heating of the target rocks, depending on the size, trajectory, and speed of the impactor (French 1998). In addition, postimpact hydrothermal activity can play a major role in terrestrial impact structures (e.g., Naumov 2002).

Three impact event processes were modeled with respect to $\% \mathrm{He}$ loss from apatite and zircon grains at Wetumpka (1) the initial fireball event; (2) shockmetamorphism; and (3) post-impact hydrothermal processes. The modeling was undertaken using authorwritten MathCAD 14 programs assuming the smallest and largest grains analyzed (radii $=29.6$ and $78.5 \mu \mathrm{m}$ for apatite, and 33.3 and $71.5 \mu \mathrm{m}$ for zircon), the minimum and maximum radii of the 5 reset grains (29.6 and $53.7 \mu \mathrm{m}$ for the 4 apatite grains, and $34.5 \mu \mathrm{m}$ for one zircon), He diffusion parameters, and the spherical (apatite; Farley 2000) and cylindrical (zircon; Reiners et al. 2004) diffusion equations of Crank (1975) (Table 2).

To calculate the duration of contact during the initial, very short, but very hot fireball event ( $>10,000 \mathrm{~K}$; French 1998), an approximate size for the projectile was calculated in two ways. The first calculation used the online Earth Impacts Effects program (Marcus et al. 2010), which combined physically relevant parameters (e.g., a final crater diameter $(6.25 \mathrm{~km})$, impact velocity $\left(17 \mathrm{~km} \mathrm{~s}^{-1}\right)$, impact angles (ranging from 10 to $90^{\circ}$ ), target and projectile densities (1,000 and 3,000 $\mathrm{kg} \mathrm{m}^{-3}$, respectively; Marcus 
Table 2. Modeled \% He losses from fireball, shock metamorphism, and hydrothermal events for Wetumpka.

\begin{tabular}{|c|c|c|c|c|c|}
\hline \multicolumn{6}{|c|}{ Fireball event } \\
\hline Mineral & $r(\mu \mathrm{m})$ & Temp $\left({ }^{\circ} \mathrm{C}\right)$ & Notes & Time (seconds) & $\%$ He loss \\
\hline Apatite & 29.6 & 1600 & Melting temp., min. \& reset grain size, $313 \mathrm{~m}$ impactor & 0.018743 & 100 \\
\hline Apatite & 29.6 & 1600 & Melting temp., min. \& reset grain size, $865 \mathrm{~m}$ impactor & 0.057285 & 100 \\
\hline Apatite & 53.7 & 1600 & Melting temp., max. reset grain size, $313 \mathrm{~m}$ impactor & 0.018743 & 100 \\
\hline Apatite & 53.7 & 1600 & Melting temp., max. reset grain size, $865 \mathrm{~m}$ impactor & 0.057285 & 100 \\
\hline Apatite & 78.5 & 1600 & Melting temp., max. grain size, $313 \mathrm{~m}$ impactor & 0.018743 & 100 \\
\hline Apatite & 78.5 & 1600 & Melting temp., max. grain size, $865 \mathrm{~m}$ impactor & 0.057285 & 100 \\
\hline Zircon & 34.5 & 2200 & Melting temp., reset grain size, $313 \mathrm{~m}$ impactor & 0.018743 & 91.1 \\
\hline Zircon & 34.5 & 2200 & Melting temp., reset grain size, $865 \mathrm{~m}$ impactor & 0.057285 & 99.8 \\
\hline Zircon & 33.3 & 2200 & Melting temp., min. grain size, $313 \mathrm{~m}$ impactor & 0.018743 & 92.3 \\
\hline Zircon & 33.3 & 2200 & Melting temp., min. grain size, $865 \mathrm{~m}$ impactor & 0.057285 & 99.9 \\
\hline Zircon & 71.5 & 2200 & Melting temp., max. grain size, $313 \mathrm{~m}$ impactor & 0.018743 & 58.5 \\
\hline Zircon & 71.5 & 2200 & Melting temp., max. grain size, $865 \mathrm{~m}$ impactor & 0.057285 & 84.4 \\
\hline \multicolumn{6}{|c|}{ Shock metamorphism event } \\
\hline Mineral & $\mathrm{r}(\mu \mathrm{m})$ & Temp $\left({ }^{\circ} \mathrm{C}\right)$ & Notes & Time (seconds) & $\%$ loss \\
\hline Apatite & 29.6 & 100 & Min. \& reset grain size & 1000 & 0 \\
\hline Apatite & 29.6 & 150 & Min. \& reset grain size & 1000 & 0.4057 \\
\hline Apatite & 53.7 & 100 & Max. reset grain size & 1000 & 0 \\
\hline Apatite & 53.7 & 150 & Max. reset grain size & 1000 & 0.4047 \\
\hline Apatite & 78.5 & 100 & Max. grain size & 1000 & 0.000 \\
\hline Apatite & 78.5 & 150 & Max. grain size & 1000 & 0.405 \\
\hline Zircon & 33.3 & 100 & Min. grain size & 1000 & 0 \\
\hline Zircon & 33.3 & 150 & Min. grain size & 1000 & 0 \\
\hline Zircon & 34.5 & 100 & Reset grain size & 1000 & 0 \\
\hline Zircon & 34.5 & 150 & Reset grain size & 1000 & 0 \\
\hline Zircon & 71.5 & 100 & Max. grain size & 1000 & 0 \\
\hline Zircon & 71.5 & 150 & Max. grain size & 1000 & 0 \\
\hline \multicolumn{6}{|c|}{ Hydrothermal event } \\
\hline Mineral & $r(\mu \mathrm{m})$ & Temp $\left({ }^{\circ} \mathrm{C}\right)$ & Notes & Time (years) & $\%$ loss \\
\hline Apatite & 29.6 & 500 & Min. \& reset grain size & 1 & 100 \\
\hline Apatite & 29.6 & 250 & Min. \& reset grain size & 30 & 100 \\
\hline Apatite & 29.6 & 150 & Min. \& reset grain size & 80 & 58.4 \\
\hline Apatite & 53.7 & 500 & Max. reset grain size & 1 & 100 \\
\hline Apatite & 53.7 & 250 & Max. reset grain size & 30 & 100 \\
\hline Apatite & 53.7 & 150 & Max. reset grain size & 80 & 34.7 \\
\hline Apatite & 78.5 & 500 & Max. grain size & 1 & 100 \\
\hline Apatite & 78.5 & 250 & Max. grain size & 30 & 100 \\
\hline Apatite & 78.5 & 150 & Max. grain size & 80 & 24.4 \\
\hline Zircon & 33.3 & 500 & Min. grain size & 1 & 100 \\
\hline Zircon & 33.3 & 250 & Min. grain size & 30 & 7.5 \\
\hline Zircon & 33.3 & 150 & Min. grain size & 80 & 0.1295 \\
\hline Zircon & 34.5 & 500 & Reset grain size & 1 & 100 \\
\hline Zircon & 34.5 & 250 & Reset grain size & 30 & 7.3 \\
\hline Zircon & 34.5 & 150 & Reset grain size & 80 & 0.1256 \\
\hline Zircon & 71.5 & 500 & Max. grain size & 1 & 95.1 \\
\hline Zircon & 71.5 & 250 & Max. grain size & 30 & 3.5 \\
\hline Zircon & 71.5 & 150 & Max. grain size & 80 & 0.07808 \\
\hline
\end{tabular}

et al. 2010), and an average $65 \mathrm{~m}$ liquid water depth over crystalline rock target type), to yield variable projectile diameters of $363-865 \mathrm{~m}$, with expected projectile velocities at the surface of $15.1-16.7 \mathrm{~km} \mathrm{~s}^{-1}$. The second projectile diameter calculation used the $1 / 20$ th of the final crater diameter estimate of French (1998), yielding a projectile diameter of $313 \mathrm{~m}$. Using the equation $\tau=L / V_{i}$, where $\tau$ is the duration of contact, $L$ is the projectile diameter $(313-865 \mathrm{~m})$, and $V_{i}$ is the impact velocity at the surface $\left(15.1-16.7 \mathrm{~km} \mathrm{~s}^{-1}\right.$; calculated from 
Marcus et al. 2010), minimum and maximum fireball event durations of 18.7 and $57.3 \mathrm{~ms}$ were calculated.

Modeling of $\% \mathrm{He}$ losses for apatite and zircon (minimum of all grains, maximum of all the grains, and the reset grain sizes) for the fireball event, assuming maximum temperatures of $1,600^{\circ} \mathrm{C}$ for apatite and $2,200{ }^{\circ} \mathrm{C}$ for zircon (i.e., the mineral melting temperatures), yielded $\% \mathrm{He}$ losses of $100 \%$ and $100 \%$ from apatite, and $58.5-92.3 \%$ and $84.4-99.9 \%$ from zircon for heating durations of 18.7 and $57.3 \mathrm{~ms}$, respectively (Table 2). It can be seen that the initial fireball event may have caused considerable resetting of the (U-Th)/He systematics, especially for apatite, but it also may have had a considerable effect on the zircon grains. However, this event would have been very localized and temperatures and durations endured would have been extremely heterogeneous.

For the shock metamorphism event, a maximum duration of 1000 seconds was estimated (Schwenzer et al. 2008). Maximum temperatures were assumed using the observed 5-15 GPa shock metamorphism effects at Wetumpka (King et al. 2002), which would have produced temperatures of $100-150{ }^{\circ} \mathrm{C}$ (French 1998). These conditions would have yielded $\% \mathrm{He}$ losses of 0 $0.406 \%$ (minimum and reset grain radius) and $0-0.405 \%$ (maximum radius) for apatite, and $0 \%$ for minimum, maximum, and reset grain sizes in zircon, for temperatures of 100 and $150{ }^{\circ} \mathrm{C}$, respectively (Table 2). Obviously, the low intensity shock metamorphism event at Wetumpka had very little effect on the (U-Th)/He systematics in the apatite and zircon grains, and cannot be the cause of (U-Th)/He age resetting in the apatite and zircon grains. The 5-15 GPa low shock levels observed at Wetumpka (King et al. 2002) may be due to shock-buffering effects associated with the watersaturated marine conditions (e.g., Buchanan et al. 1998). In addition, the samples analyzed are impact breccias, therefore they will most likely contain strongly mixed and reworked target rock clasts that have undergone different heating, cooling, shocking, and possible water quenching conditions.

Post-impact hydrothermal conditions at Wetumpka are unknown. However, recent mineralogical and geothermal modeling has been undertaken on the Kärdla impact structure in Estonia (Jõeleht et al. 2005; Versh et al. 2005). This impact structure is very similar to Wetumpka, as it has a crater diameter of $4 \mathrm{~km}$ and was also a shallow-marine impact event $(<100 \mathrm{~m}$ water depth). Therefore, the hydrothermal event of Kärdla impact structure (Jõeleht et al. 2005) was used as a proxy for Wetumpka. Using the maximum predicted hydrothermal temperature of $500{ }^{\circ} \mathrm{C}$ for $1 \mathrm{yr}$ duration at Kärdla, we calculated ${ }^{4} \mathrm{He}$ losses of $100 \%$ and $95-100 \%$ in apatite and zircon (minimum, maximum, and reset grains sizes), respectively. Using more moderate hydrothermal temperatures of $250{ }^{\circ} \mathrm{C}$ for a duration of $30 \mathrm{yr}$ (Jõeleht et al. 2005), \% He losses of $100 \%$ for apatite (minimum, maximum, and reset grain sizes), and $3.5-7.5 \%$ for zircon (minimum, maximum, and reset grains sizes) were calculated for Wetumpka grains. Low temperature hydrothermal temperatures of $150{ }^{\circ} \mathrm{C}$ for a duration of 80 years yielded $\%$ He losses of $24-58 \%$ for apatite, and $0.078-0.13 \%$ for zircon (Table 2). However, hydrothermal heating can be an extremely heterogeneous process, even at a small scale, with observed heatshielding of grains and fossils occurring within clasts (e.g., Gattacceca et al. 2011). Depending on the hydrothermal conditions undergone by our 5 impact breccia samples, they could have either endured lowtemperature conditions with low He losses, or complete or near complete (U-Th)/He age resetting via mediumto high-temperature conditions.

There were no observable optical microscope differences between the appearance of the reset, partially reset, and non-reset grains (Fig. 2). There were no correlations with $\mathrm{U}$ and $\mathrm{Th}$ concentrations (expressed as $\mathrm{eU}$, which weights $\mathrm{U}$ and $\mathrm{Th}$ for their $\alpha$ particle productivity $(\mathrm{eU}=[\mathrm{U}]+0.235[\mathrm{Th}]) \quad$ (e.g., Flowers et al. 2007) and (U-Th)/He ages in the apatite and zircon grains (Figs. $4 \mathrm{a}$ and $4 \mathrm{~b}$ ). There was no observed correlation between the apatite and zircon grain dimensions and (U-Th)/He ages (Fig. 5), which suggests that the thermal effects in these samples were very heterogeneous. In addition, there were no correlations between the (U-Th)/He apatite and zircon ages and well depth for the five samples obtained from the two drill core wells (Fig. 6).

Actual $\% \mathrm{He}$ losses from 21 apatite and 24 zircon single grain analyses were $0-100 \%$ for apatite and zircon. To calculate the actual $\% \mathrm{He}$ losses, we estimated initial zircon and apatite target rock ages for the Piedmont schists and gneisses. We used an (U-Th)/He target rock apatite age (from a cluster of 6 old apatite ages) of $155.4 \pm 6.2 \mathrm{Ma}(2 \sigma$, Table 1$)$, thereby ignoring two older apatite ages of $242.3 \pm 23.7$ and $170.3 \pm 15.1 \mathrm{Ma}(2 \sigma)$, which had large errors and low $\mathrm{U}$ and $\mathrm{Th}$ concentrations (Table 1). An initial (U-Th)/He target rock zircon age of $254.0 \pm 7.7 \mathrm{Ma}(2 \sigma)$ was used, the oldest of a cluster of 6 zircon ages (Table 1). These estimated (U-Th)/He target rock ages are within errors of Piedmont-Coastal Plain unconformity (U-Th)/He apatite and zircon ages from an Alabama-Georgia traverse, which preserve metamorphic cooling ages in the range of 175.3-118.5 and 231.7162.7 Ma, respectively (Layfield 2009), following the Alleghanian orogeny at approximately $300-310 \mathrm{Ma}$ (Johnson et al. 2006; Layfield 2009). The presence of older $(\mathrm{U}-\mathrm{Th}) / \mathrm{He}$ ages in 3 apatites $(152.1-242.3 \mathrm{Ma})$ and 5 zircons (238.1-254.0 Ma) in these impact breccias suggests 

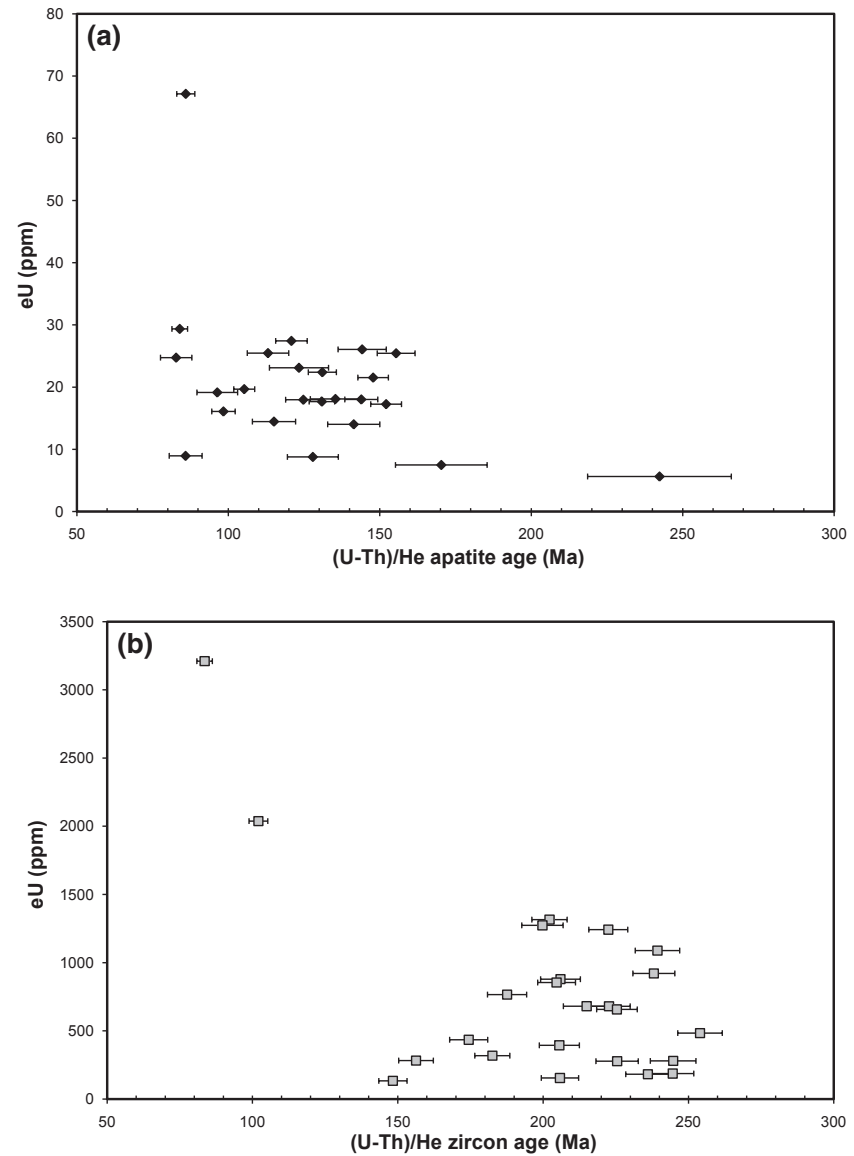

Fig. 4. eU versus (U-Th)/He age for (a) apatite and (b) zircon grains. No errors are shown for the eU values, as they are based on an assumed ideal crystal shape and the measured grain dimensions, therefore it is difficult to reliably constrain an error for this assumption.

that some grains were almost completely undegassed (i.e., $<10 \% \mathrm{He}$ loss; Table 1) by the impact event. These older (U-Th)/He ages agree with regional ${ }^{40} \mathrm{Ar} /{ }^{39} \mathrm{Ar}$ and (U-Th)/He metamorphic cooling ages, following the approximately 300-310 Ma Alleghanian orogeny (Johnson et al. 2006; Layfield 2009).

Figure 7 shows a histogram of the actual $\% \mathrm{He}$ losses from individual apatite and zircon grains. The analyzed zircons only contained 1 grain that experienced $100 \%$ He loss, 4 grains with $>50 \%$ He loss, and 8 grains with $>25$ to $<50 \%$ He loss. By contrast, the analyzed apatites contained 4 grains that experienced $100 \% \mathrm{He}$ loss, 9 grains with $>50 \% \mathrm{He}$ loss, and 7 grains with $>25$ to $<50 \% \mathrm{He}$ loss. This \% He loss difference between zircon and apatite is expected, given the faster He diffusion rate in apatite versus that in zircon (Farley 2000; Reiners et al. 2004). Modeled versus actual \% $\mathrm{He}$ losses from the fireball, hydrothermal, and fireball + hydrothermal events show comparable results (Table 2;

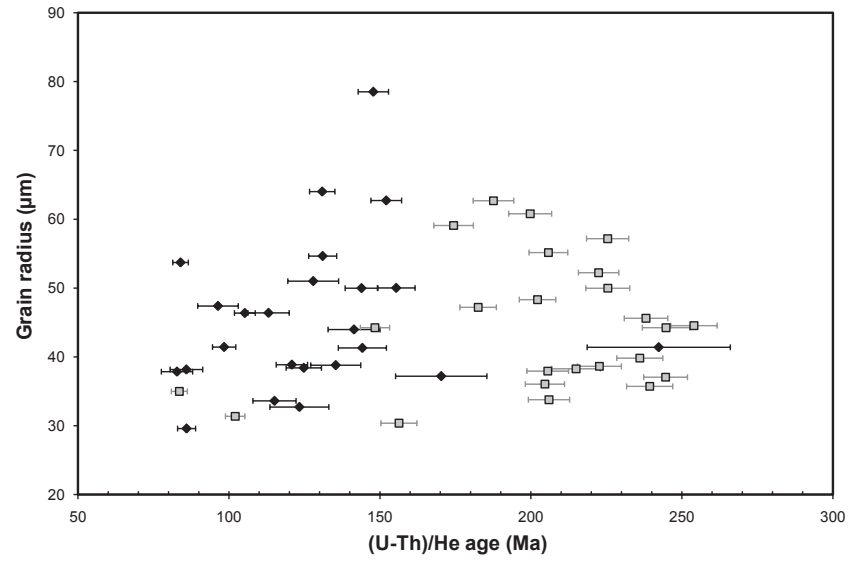

Fig. 5. (U-Th)/He age versus grain radius, for apatite (black diamonds) and zircon (grey squares).

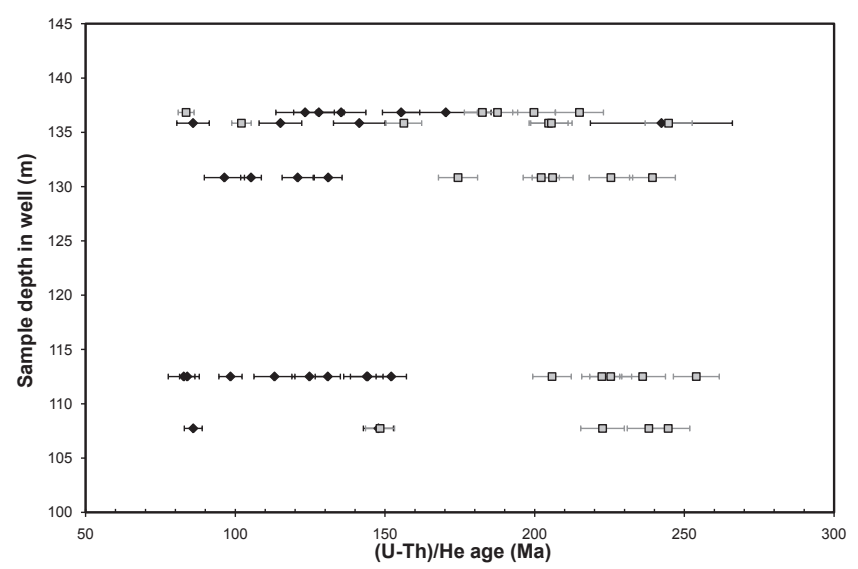

Fig. 6. (U-Th)/He age versus the average drill core sample depth for wells 98-01 (107.7-135.9 m) and 98-02 (112.5$136.9 \mathrm{~m}$ ), for apatite (black diamonds) and zircon (grey squares) grains.

Fig. 7); however, shock metamorphism appears to have had very little effect in these rocks during the Wetumpka impact event. This indicates that although impact and hydrothermal fluid heating temperatures and durations in these target rocks may have been extremely heterogeneous, under the right fireball/hydrothermal conditions, it is possible to completely reset the (U$\mathrm{Th} / \mathrm{He}$ ) ages in apatites and zircons during small marine impact events, such as occurred at Wetumpka.

In contrast, biotite $\mathrm{Ar} \%$ losses were also modeled, assuming a $50 \mu \mathrm{m}$ radius, activation energy, and frequency factor values $\mathrm{Ar}$ diffusion of (Grove and Harrison 1996), a cylindrical diffusion geometry, and dry and wet melting temperatures of 850 and $700{ }^{\circ} \mathrm{C}$, respectively. They yielded very low losses of $0 \%$ for the fireball event, $0 \%$ for a 1000 seconds shock metamorphism event, $11.4 \%$ for the $500{ }^{\circ} \mathrm{C}$ for $1 \mathrm{yr}$ hydrothermal event, and $0 \%$ losses for the lower 


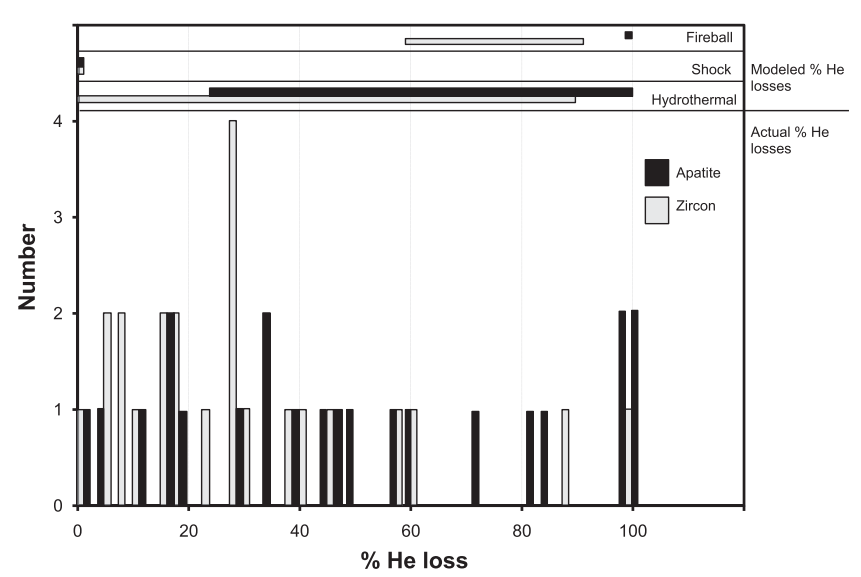

Fig. 7. Histogram of actual $\% \mathrm{He}$ losses from individual apatite and zircon grains (bottom plot), assuming original target ages of 155.4 and $254.0 \mathrm{Ma}$, respectively, and an impact age of $84.4 \mathrm{Ma}$. The modeled \% He loss estimates for the fireball, shock metamorphism, and hydrothermal events are shown at the top of the plot.

temperature $250{ }^{\circ} \mathrm{C}$ for $30 \mathrm{yr}$, and $150{ }^{\circ} \mathrm{C}$ for $80 \mathrm{yr}$ hydrothermal events. This indicates that ${ }^{40} \mathrm{Ar} /{ }^{39} \mathrm{Ar}$ or $\mathrm{K}-\mathrm{Ar}$ dating of non-melted biotite is probably not a viable technique for dating the Wetumpka impact structure. The calculated biotite Ar closure temperature of $300{ }^{\circ} \mathrm{C}$ (calculated for a $50 \mu \mathrm{m}$ radius grain with a $10{ }^{\circ} \mathrm{C} / \mathrm{Ma}$ cooling rate) is one of the lowest closure temperatures for the traditionally used geochronometers. Therefore, the other higher temperature $\mathrm{K}-\mathrm{Ar}, \mathrm{Rb}-\mathrm{Sr}$, $\mathrm{Sm}-\mathrm{Nd}$, and $\mathrm{U}-\mathrm{Pb}$ geochronometers will probably show very little to no evidence of resetting during the formation of small and low-energy impact structures.

\section{DISCUSSION}

The $23(\mathrm{U}-\mathrm{Th}) / \mathrm{He}$ zircon ages and $24(\mathrm{U}-\mathrm{Th}) / \mathrm{He}$ apatite ages are all younger than the ${ }^{40} \mathrm{Ar}-{ }^{39} \mathrm{Ar}$ white mica approximately 300-310 Ma regional Appalachian basement deformation age (Johnson et al. 2006; Layfield 2009), and the oldest ages are within error of regional cooling (U-Th)/He apatite and zircon ages for the Piedmont-Coast Plain region (Layfield 2009). Some of the older (U-Th)/He ages could reflect regional Piedmont/ Coastal Plain cooling ages (e.g., Layfield 2009), but the younger range of ages reflects partial to complete resetting of the (U-Th)/He zircon and apatite ages, most probably during the Wetumpka impact event. The Wetumpka impact event was not high enough in temperature, shocking pressure, or duration to cause the complete loss of radiogenic ${ }^{4} \mathrm{He}$ in all the zircon and apatite grains, as evidenced by the large range of (U-Th)/He ages (82.8254.0 Ma) recorded in the 47 grains (Fig. 3).

The mean apatite and zircon (U-Th) $/ \mathrm{He}$ age of $84.4 \pm 1.4 \mathrm{Ma}$ is within error of the latest biostratigraphic age of approximately $83.5 \mathrm{Ma}$ (King et al. 2006b). As both the apatite and zircon analyses give the same youngest age, this young mean age most likely reflects the age of the formation for the Wetumpka impact structure. If these young ages had been the result of any other reheating and/or slow cooling event, the distinctly different closure temperatures for these two minerals would not have yielded this overlapping young age cluster.

Schärer and Deutsch (1990) and Deutsch and Schärer (1994) state that only $10 \%$ of the target rocks and minerals are completely reset during hypervelocity impact events, and this percentage may be even lower for low melt/suevite-producing marine impact structures (e.g., Buchanan et al. 1998). However, this $10 \%$ only relates to the conditions necessary to allow complete melting and/or thermal resetting of common hightemperature geochronometers (e.g., ${ }^{40} \mathrm{Ar} /{ }^{39} \mathrm{Ar}$, U-Pb, $\mathrm{K}-\mathrm{Ar}, \mathrm{Sm}-\mathrm{Nd}$, Rb-Sr, etc.) in the target impact rocks. This is important, as dating of non-molten rocks would expand both the amount and type of material available to date at large impact sites, plus should allow dating of small- to medium-sized craters, which have not yet yielded any radiometric ages due to lack of suitable material for other geochronological techniques. Given the fast $\mathrm{He}$ diffusion properties in apatite and zircon (Farley 2000; Reiners et al. 2004), modeled impact thermal events can result in partial and/or total resetting of the low-temperature (U-Th)/He geochronometers, whereas common chronometers (e.g., ${ }^{40} \mathrm{Ar} /{ }^{39} \mathrm{Ar}$ in biotite) may not be reset or are only reset by very small amounts. While single-crystal (U-Th)/He dates generally have lower precision (e.g., $3-10 \% 2 \sigma$ ) than typical ${ }^{40} \mathrm{Ar} /{ }^{39} \mathrm{Ar}$ and $\mathrm{U}-\mathrm{Pb}$ ages, multiple replicate analyses of grain aliquots can be determined relatively easily and can be very accurate (Hourigan et al. 2005).

\section{CONCLUSIONS}

The (U-Th)/He dating technique is proving to be a potentially powerful tool for dating large (e.g., $90 \mathrm{~km}$ diameter Manicouagan; van Soest et al. 2011), medium (e.g., $40 \mathrm{~km}$ diameter Lake Saint Martin; Wartho et al. 2010), and small impact structures (e.g., $350 \mathrm{~m}$ diameter Monturaqui; Ukstins Peate et al. 2012).

Small and marine impact structures are extremely difficult to date using conventional geochronological techniques (e.g., U-Pb, Rb-Sr, Sm-Nd, and ${ }^{40} \mathrm{Ar}-{ }^{39} \mathrm{Ar}$ ), which generally rely on high-temperature syn- and postimpact events to reset most commonly applied isotopic geochronometers. However, the (U-Th)/He apatite and zircon geothermometers have the combined unique properties of (1) low-temperature closure temperatures, and (2) fast He diffusivity (Farley 2000; Reiners et al. 2004). This results in rapid and more effective resetting of 
the $(\mathrm{U}-\mathrm{Th}) / \mathrm{He}$ grain ages during short-lived impact events than might be expected for more commonly utilized chronometers. Although the (U-Th)/He dating technique does not provide the same precision as other geochronometers, nevertheless, it can still yield accurate impact ages, with a typical $2 \sigma$ error single grain age precision of approximately $3-10 \%$, and in many instances the precision can be better (Hourigan et al. 2005).

From a total of 47 (U-Th)/He analyzed zircon and apatite grains, five grains (one zircon and four apatites) gave the youngest cluster of ages, yielding a mean $(\mathrm{U}-\mathrm{Th}) / \mathrm{He}$ age of $84.4 \pm 1.4 \mathrm{Ma}(2 \sigma)$. This geochronological age is within error of the previous Wetumpka stratigraphic age estimate of approximately 83.5 Ma (King et al. 2006b), and represents the first radiometric age obtained for this impact structure. The successful geochronological dating of the approximately $6.25 \mathrm{~km}$ diameter Wetumpka impact structure has additionally highlighted the viability of the (U-Th)/He dating technique to date impact structures characterized by low levels of shock and melting, as is commonly observed in rocks of marine impact structures (e.g., Buchanan et al. 1998; Dypvik and Jansa 2003). In particular, the (U-Th)/He method appears promising for absolute dating of impact structures that lack impact melt lithologies, because of their small size or eroded state.

Acknowledgments - This work was partially supported by NASA PGG grant \# NNX09AD90G (King) and NSF grant \# EAR-0948143 (Wartho and van Soest). We thank Martin Schmieder, one anonymous reviewer, and editorial comments from John Spray for their detailed and very helpful reviews, which have improved this manuscript.

\section{Editorial Handling - Dr. John Spray \\ REFERENCES}

Buchanan P. C., Koeberl C., and Reid A. M. 1998. Impact into unconsolidated, water-rich sediments at the Marquez Dome, Texas. Meteoritics \& Planetary Science 33:1053-1064.

Collins G. S., Melosh H. J., and Marcus R. A. 2005. Earth impact effects program: A web-based computer program for calculating the regional environmental consequences of a meteoroid impact on Earth. Meteoritics \& Planetary Science 40:817-840.

Crank J. 1975. The mathematics of diffusion. London: Oxford University Press. 414 p.

Deutsch A. and Schärer U. 1994. Dating terrestrial impact events. Meteoritics \& Planetary Science 29:301-322.

Dypvik H. and Jansa L. F. 2003. Sedimentary signatures and processes during marine bolide events: A review. Sedimentary Geology 161:309-337.

Earth Impact Database. 2012. http://www.unb.ca./passc /Impact Database/Planetary and Space Science Centre.University of New Brunswick. Accessed January 2012.
Evans N. J., Byrne J. P., Keegan J. T., and Dotter L. E. 2005. Determination of uranium and thorium in zircon, apatite, and fluorite: Application to laser (U-Th)/He thermochronology. Journal of Analytical Chemistry 60:1159-1165.

Farley K. A. 2000. Helium diffusion from apatite: General behavior as illustrated by Durango fluorapatite. Journal of Geophysical Research 106(B2):2903-2914.

Farley K. A. 2002. (U-Th)/He dating: Techniques, calibrations, and applications. In Noble gases in geochemistry and cosmochemistry, edited by Procelli D., Ballentine C. J., and Wieler R. Reviews in Mineralogy and Geochemistry, vol. 47. Washington D.C.: The Mineralogical Society of America. pp. 819-844.

Farley K. A., Wolf R. A., and Silver L. T. 1996. The effects of long alpha-stopping distances on (U-Th)/He ages. Geochimica et Cosmochimica Acta 60:4223-4229.

Flowers R. M., Shuster D. L., Wernicke B. P., and Farley K. A. 2007. Radiation damage control on apatite (U-Th)/He dates from the Grand Canyon region, Colorado Plateau. Geology 35:447-450.

French B. M. 1998. Traces of catastrophe: A handbook of shockmetamorphic effects in terrestrial meteorite impact structures. LPI Contribution 954. Houston: Lunar Planetary Institute. $120 \mathrm{p}$.

Gattacceca J., Osinski G. R., Quesnel Y., and Rochette R. 2011. Emplacement temperature of the impact breccia at Haughton impact crater (abstract \#5284). $74^{\text {th }}$ Meteoritical Society Meeting. 8-12 August 2012. London. Meteoritics \& Planetary Science 46.

Gradstein F., Ogg J., and Smith A. 2004. A geologic time scale. Cambridge, UK: Cambridge University Press. 599 p.

Grove M. and Harrison T. M. 1996. ${ }^{40} \mathrm{Ar}^{*}$ diffusion in Fe-rich biotite. American Mineralogist 81:940-951.

Haq B. U., Hardenbol J., and Vail P. R. 1988. Mesozoic and Cenozoic chronostratigraphy and eustatic cycles. In Sealevel changes: An integrated approach, edited by Wilgis C. K., Hastings B. S., Bendall G. C. St. C., Posamentier H. W., Ross C. A., and van Wagoner J. C. Tulsa, Oklahoma: Society of Economic Paleonologists and Mineralogists Special Publications 42. pp. 71-108.

Hourigan J. K., Reiners P. W., and Brandon M. T. 2005. U-Th zonation-dependent alpha-ejection in (U-Th)/He chronometry. Geochimica et Cosmochimica Acta 69:3349-3365.

Jõeleht A., Kirsimäe K., Plado J., Versh E., and Ivanov B. 2005. Cooling of the Kärdla impact crater: II. Impact and geothermal modeling. Meteoritics \& Planetary Science 40:21-33.

Johnson R. C. 2007. Wetumpka impact structure modeled as the exposed remains of a large, shallow-water, marinetarget crater for analysis and interpretation of two drill cores taken from near the structure's geographical center. Master's thesis, Auburn University, Auburn, Alabama, USA.

Johnson R. C., Petruny L. M., Hames W. E., and King D. T., Jr. 2006. Shock metamorphic characteristics and age of the Wetumpka impact structure, Alabama (abstract). Geological Society of America Abstracts with Programs 38:3, 82.

King D. T., Jr. 1997. The Wetumpka impact crater and the Late Cretaceous impact record, vol. 34c. Tuscaloosa: Alabama Geological Society Guidebook. pp. 25-56.

King D. T., Jr. and Ormö J. 2011. The marine-target Wetumpka impact structure examined in the field and by shallow corehole drilling. In Analogs for planetary exploration, edited by Garry W. B. and Bleacher J. E. GSA Special Publication 
483. Boulder, Colorado: Geological Society of America. pp. 287-300.

King D. T., Jr., Neathery T. L., Petruny L. W., Koeberl C., and Hames W. E. 2002. Shallow marine-impact origin for the Wetumpka structure. Earth and Planetary Science Letters 202:541-549.

King D. T., Jr., Neathery T. L., and Petruny L. W. 2003. Crater-filling sediments of the Wetumpka marine-target impact crater (Alabama, USA). In Cratering in marine environments and on ice, edited by Dypvik H., Burchell M. J., and Claeys P. Berlin: Springer-Verlag. pp. 97-113.

King D. T., Jr., Petruny L. W., and Neathery T. L. 2006 a. Paleobiotic effects of the Late Cretaceous Wetumpka marine impact, a $7.6 \mathrm{~km}$ diameter impact structure, Gulf Coastal Plain, USA. In Biotic effects of impacts, edited by Cockell C. S. Berlin: Springer. pp. 121-142.

King D. T., Jr., Ormö J., Petruny L. W., and Neathery T. L. 2006b. Role of water in the formation of Late Cretaceous Wetumpka impact structure, inner Gulf Coastal Plain of Alabama, USA. Meteoritics \& Planetary Science 41:1625-1631.

King D. T., Jr., Petruny L. W., and Neathery T. L. 2007. Ecosystem perturbation caused by the Late Cretaceous marine impact, Gulf Coastal Plain, USA. GSA Special Paper 424. Boulder, Colorado: Geological Society of America. pp. 97-107.

Layfield N. T. 2009. Permian to Cretaceous evolution of the Piedmont along the Alabama-Georgia Coastal Plan unconformity. Master's thesis, Auburn University, Auburn, Alabama, USA.

Ludwig K. R. 2008. User's manual for Isoplot 3.70: A geochronological toolkit for Microsoft Excel. Berkeley, California: Berkeley Geochronology Center Special Publication 4.77 p.

Mancini E. A., Puckett T. M., Parcell W. C., Crow C. J., and Smith C. C. 1988. Sequence stratigraphy and biostratigraphy of Upper Cretaceous strata of the Alabama Coast Plain. In Sequence stratigraphy and biostratigraphy of Upper Cretaceous strata of the Alabama Coastal Plain: Tuscaloosa, edited by Mancini E. A. and Puckett T. M. Tuscaloosa: Alabama Geological Society Guidebook. 35. pp. $1-12$.

Marcus R., Melosh H. J., and Collins G. 2010. Online Earth Impact Effects program. http://impact.ese.ic.ac.uk/ ImpactEffects/.

Miller D. S. and Wagner G. A. 1979. Age and intensity of thermal events by fission track analysis: The Ries impact crater. Earth and Planetary Science Letters 43:351-358.

Milton D. J. and Macdougall F. A. 2006. Goat Paddock, Western Australia: An impact crater near the simplecomplex transition. Australian Journal of Earth Sciences 52:689-697.

Naumov M. A. 2002. Impact-generated hydrothermal systems: Data from Popogai, Kara, and Puchezh-Katunki impact structures. In Impacts in Precambrian shields, edited by Plado J. and Pesonen L. Berlin: Springer. pp. 117-171.

Neathery T. L., Bentley R. D., and Lines G. C. 1976. Cryptoexplosive structure near Wetumpka, Alabama. Geological Society of America Bulletin 87:567-573.

Ogg J. G., Ogg G., and Gradstein F. 2008. The concise geologic time scale. Cambridge, UK: Cambridge University Press. $150 \mathrm{p}$.
Reiners P. W. 2005. Zircon (U-Th)/He thermochronometry. In Low-temperature thermochronology: Techniques, interpretations, and applications, edited by Reiners P. W. and Ehlers T. A. Reviews in Mineralogy and Geochemistry, vol. 58. Washington D.C.: The Mineralogical Society of America. pp. 151-179.

Reiners P. W., Farley K. A., and Hickes H. J. 2002. He diffusion and (U-Th)/He thermochronometry of zircon: Initial results from Fish Canyon Tuff and Gold Butte. Tectonophysics 349:297-308.

Reiners P. W., Spell T. L., Nicolescu S., and Zanetti K. A. 2004. Zircon (U-Th)/He thermochronometry: He diffusion and comparisons with ${ }^{40} \mathrm{Ar} /{ }^{39} \mathrm{Ar}$ dating. Geochimica et Cosmochimica Acta 68:1857-1887.

Schärer U. and Deutsch A. 1990. Isotope systematics and shock-wave metamorphism: II. U-Pb and $\mathrm{Rb}-\mathrm{Sr}$ in naturally shocked rocks; the Haughton Impact Structure, Canada. Geochimica et Cosmochimica Acta 54:3435-3447.

Schmieder M., and Buchner E. 2008. Dating impact craters: Palaeogeographic versus isotopic and stratigraphic methods-A brief case study. Geological Magazine 145:586590.

Schwenzer S. P., Fritz J., Stöffler D., Trieloff M., Amini M., Greshake A., Herrmann S., Herwig K., Jochum K. P., Mohapatra R. K., Stoll B., and Ott U. 2008. Helium loss from Martian meteorites mainly induced by shock metamorphism: Evidence from new data and a literature compilation. Meteoritics \& Planetary Science 43:1841-1859.

Spotila J. A., Farley K. A., and Sich K. 1998. Uplift and erosion of the San Bernardino Mountains associated with transpression along the San Andreas fault, California, as constrained by radiogenic helium thermochronometry. Tectonics 17:360-378.

Ukstins Peate I., Wartho J.-A., van Soest M. C., Cabrol N. A., Grin E. A., and Chong G. 2012. Geochronological dating of a small and young impact structure-Monturaqui Crater, Chile. Earth and Planetary Science Letters.

van Soest M. C., Hodges K. V., Wartho J.-A., Biren M. B., Monteleone B. D., Ramezani J., Spray J. G., and Thompson L. M. 2011. (U-Th)/He dating of terrestrial impact structures: The Manicouagan example. Geochemistry Geophysics Geosystems 12:Q0AA16, doi:1029/2010GC003465.

Versh E., Kirsimäe K., Jõeleht A., and Plado J. 2005. Cooling of the Kärdla impact crater: I. The mineral paragenetic sequence observation. Meteoritics \& Planetary Science 40:3-19.

Wagner G. A. and Storzer D. 1975. The age of the Rochechouart impact structure. Meteoritics 10:503-504.

Wartho J.-A., van Soest M. C., Cooper F. J., Hodges K. V., Spray J. G., Schmieder M., Buchner E., Bezys R. K., and Reimold W. U. 2010. Updated (U-Th)/He zircon ages for the Lake Saint Martin impact structure (Manitoba, Canada) and implications for the Late Triassic multiple impact theory (abstract \#1930). 41st Lunar and Planetary Science Conference. CD-ROM.

Weber J. C., Poulos C., Donelick R. A., Pope M. C., and Heller N. 2005. The Kentland impact crater, Indiana (USA): An apatite fission-track age determination attempt. In Impact tectonics, edited by Koeberl C. and Henkel D. H. Berlin: Springer. pp. 447-466. 